\title{
Refrigerated storage of pork meat sprayed with rosemary extract and ascorbic acid
}

\section{Flavia Perlo $^{1^{*}}$ () Romina Fabre $^{1} \odot$ Patricia Bonato $^{1}$ Carolina Jenko ${ }^{1} \odot$ Osvaldo Tisocco $^{1}$ Gustavo Teira $^{1}$}

${ }^{1}$ Facultad de Ciencias de la Alimentación, Universidad Nacional de Entre Ríos (UNER), Tavella 1450, Concordia, ER, Argentina. E-mail: perlof@fcal.uner.edu.ar. "Corresponding author.

ABSTRACT: There is an increasing consumer demand to avoid the use of synthetic additives like many antioxidants currently added to food. The objective of this study was to determine the effect of spraying ascorbic acid, rosemary extract and a combination of both on pork meat during refrigerated storage. Pork meat with antioxidants sprayed on the surface was packaged under vacuum and stored $\left(4^{\circ} \mathrm{C}, 45 \mathrm{~d}\right) . \mathrm{pH}$, color, lipid oxidation, total aerobic count, drip loss and moisture were evaluated during storage. Results suggested that surface application of rosemary extract and a combination of rosemary extract and ascorbic acid resulted in an effective delay of lipid oxidation of pork meat, without affecting $\mathrm{pH}$, colour or water content during storage. No effect of rosemary extract on microbial growth was observed. Key words: natural antioxidants, oxidation, storage, meat quality.

Armazenamento resfriado de carne de porco pulverizada com extrato de alecrim e ácido ascórbico

RESUMO: Existe uma crescente demanda dos consumidores para evitar o uso de aditivos sintéticos como muitos antioxidantes atualmente adicionados aos alimentos. O objetivo deste estudo foi determinar o efeito da pulverização de ácido ascórbico, extrato de alecrim e uma combinação de ambos na carne de porco durante o armazenamento resfriado. A carne de porco com antioxidantes pulverizados na superficie foi embalada sob vácuo e armazenada $\left(4^{\circ} \mathrm{C}, 45 \mathrm{~d}\right) . \mathrm{pH}$, cor, oxidação lipídica, contagem de microrganismos aerobios totais, perda por gotejamento e umidade foram avaliados durante o armazenamento. Os resultados sugerem que a aplicação superficial de extrato de alecrim e uma combinação de extrato de alecrim e ácido ascórbico resultaram no atraso efetivo da oxidação lipídica da carne de porco, sem afetar o pH, cor ou teor de água ao longo do armazenamento. Nenhum efeito do extrato de alecrim no crescimento microbiano foi observado. Palavras-chave: antioxidantes, oxidação, armazenamento, qualidade de carne.

\section{INTRODUCTION}

Industry seeks to maintain the primary quality of meat during processing and storage, but in some instances, increased life provided by cooling may be insufficient. Lipid oxidation will possibly generate undesirable organoleptic characteristics whereas microbial growth may cause both spoilage and food borne diseases. Therefore, delaying lipid oxidation and preventing bacterial growth are factors that can have a significant contribution towards the extension of shelf life (GEORGANTELIS et al., 2007). Nowadays, there is increasing consumer awareness and healthconsciousness which result in pressure to avoid the use of synthetic additives (GEORGANTELIS et al., 2007; NAVEENA et al., 2008).
Rosemary (Rosmarinus officinalis) has a high content of polyphenols which have demonstrated antioxidant activity. Moreover certain compounds have been reported as responsible for antimicrobial activity (DELCAMPOetal.,2000).NISSENetal.(2004)observed a decrease in TBARS (Thiobarbituric Acid Reactive Substances) and hexanal in cooked pork hamburgers, as a result of adding rosemary extract (200ppm) into the formulation. SÁNCHEZ-ESCALANTE et al. (2001) obtained similar results using 1000ppm rosemary powder on beef burgers. ROJAS \& BREWER (2008) reported lower TBARS values than the control without oleoresins when exploring the effect of rosemary oleoresins $(0.02 \%)$ in pork burgers (packed under vacuum and frozen). In all these studies, rosemary is added in powder form into the formulation or as a solution to minced meat. 
Ascorbic acid (vitamin C) is a natural antioxidant. DECKER \& XU (1998) reported that ascorbic acid inhibits lipid oxidation in meat products depending on its concentration. MITSUMOTO et al. (1991) evaluated the effect of vitamin C (500mg/ $\mathrm{kg}$ of meat) on the conservation of minced beef and observed a greater stability of pigment and lower lipid oxidation values. Furthermore, it has been reported that ascorbic acid can act as a synergist agent when used in combination with other antioxidants (ELLIOTT, 1999). SÁNCHEZ-ESCALANTE et al. (2003) reported that vitamin $\mathrm{C}$ improves the antioxidant effect of rosemary extract in beef burgers during 16 days of refrigerated storage. In beef burgers, these authors observed a positive effect of rosemary and vitamin C combination on the red color after 20 days of storage (SÁNCHEZ-ESCALANTE et al., 2001).

According to these results, the use of natural antioxidants in the preservation of meat is promising. However, there is little information on its effectiveness in fresh pork meat and its addition by spraying. This method would allow the application of natural antioxidants on the surface of fresh meat easily, with low cost and accessible to retailers. DJENANE et al. (2002) sprayed different antioxidants (vitamin E, taurine and rosemary, in combination with vitamin C) on fresh beef steaks packaged in modified atmosphere. DJENANE et al. (2003) investigated the effect of rosemary extract in combination with vitamin $\mathrm{C}$ under UV-free lighting in beef steaks packaged in modified atmosphere. In these studies the use of natural antioxidants by spraying rendered interesting results. The aim of the present research was to study the effect of spraying rosemary extract, ascorbic acid and a combination of both, during storage of fresh pork meat packaged under vacuum.

\section{MATERIALS AND METHODS}

Longissimus dorsi pork muscles were purchased from a local abattoir $48 \mathrm{~h}$ after slaughter. From each muscle, pork steaks (pork loin medallion steaks) of about $150 \mathrm{~g}$ weight and $2.5 \mathrm{~cm}$ thick were taken. They were divided into four groups and treated as follows: (1) spraying with $1 \mathrm{ml}$ of pure commercial rosemary alcoholic extract (RE) (Laboratorio Alsina) with $4000 \mathrm{ppm}$ total phenols previously determined by Folin-Ciocalteu reagent; (2) spraying with $1 \mathrm{ml}$ of 1-ascorbic acid solution (AA), 500ppm freshly prepared (Sigma Chemical Co); (3) spraying with $1 \mathrm{ml}$ of a freshly prepared mixture with pure commercial rosemary extract and 1-ascorbic acid solution in 1:1 ratio ( $\mathrm{RE}+\mathrm{AA}$ ); and (4) without antioxidants (control). As steaks were being sprayed, they were individually placed in bags and vacuum packaged (Multivac, Sepp Haggenmüller $\mathrm{GmbH}$ \& Co.KG, Germany). Bags had an oxygen transmission rate $<25 \mathrm{cc} / \mathrm{m}^{2} / 24 \mathrm{~h}$ at $4^{\circ} \mathrm{C}$. Bags were stored in darkness at $4 \pm 1^{\circ} \mathrm{C}$ for $45 \mathrm{~d}$. Steaks of each treatment (n: 6) were analyzed at 0,15 , 30 and 45 days of refrigerated storage.

\section{Analytical determinations}

Pork meat was taken out of the bag once the set storage times were reached. Each steak was weighed for drip loss measurement and material for microbiological determination was separated, both procedures done under aseptically conditions. The $\mathrm{pH}$ and color were measured on the remaining sample which was then frozen (and vacuum packaged) for TBARS (Thiobarbituric Acid Reactive Substances) and moistures analysis. The $\mathrm{pH}$ was measured with a portable pHmeter (35805-18 Model, Oakton, Singapore) with glass puncture electrode. Moisture content was determined following the drying air method (AOAC 950.46, 2005). Drip loss was calculated as the difference between the initial steak weight (before packaging) and final weight (after the corresponding storage period) and expressed as a percentage of the initial weight. Lipid oxidation was assessed by TBARS using the aqueous extraction method (PIKUL et al., 1989). Meat samples were thawed $\left(24 \mathrm{~h}, 4^{\circ} \mathrm{C}\right)$ and they immediately were ground $(10 \mathrm{~g})$ and homogenized with cold extracting solution containing $4 \%$ perchloric acid. The blended sample was filtered through Whatman No. 1 filter paper. The filtrate was adjusted to $50 \mathrm{~mL}$ by adding $4 \%$ perchloric acid. Next, 5-mL aliquots of the filtrate were transferred to separate test tubes and mixed with $5 \mathrm{~mL}$ of $0.02 \mathrm{M}$ TBA. Tubes were incubated in a boiling water bath for $1 \mathrm{~h}$ and then cooled for $10 \mathrm{~min}$ with cold tap water. Absorbance of the supernatant was measured at $532 \mathrm{~nm}$ against a blank containing $5 \mathrm{~mL}$ of $4 \%$ perchloric acid and $5 \mathrm{~mL}$ of $0.02 \mathrm{M}$ TBA solutions in a spectrophotometer (Shimadzu UV-1800). Standard curve was built using $1 \mathrm{mM}$ $1,1,3,3$ tetraethoxy-propane stock solutions. Results were expressed as mg malondialdehyde (MDA)/ $\mathrm{kg}$ meat. Surface meat color was determined using a reflectance spectrophotometer Minolta CM700d (Minolta Camera Co, Osaka, Japan), with A light source and $10^{\circ}$ observer angle. Lightness $L^{*}$, redness $a^{*}$ and yellowness $b^{*}$ (CIE, 1978) were evaluated after keeping the samples for $30 \mathrm{~min}$ at room temperature. Pork meat was analyzed for the total count of aerobic bacteria with Compact Dry ${ }^{\circledR}$ 
TC test method (R-Biopharm AG, Germany). Pork tissue (about $10 \mathrm{~g}$ ) in a sterile packaging was mixed with sterile peptone water (Britania ${ }^{\circledR}$ Argentina) until reaching $100 \mathrm{~g}$, and vigorously homogenized (Masticator, IUL Instruments) for 120s. The aqueous phase was serially diluted according to the increase in total aerobic counts number during storage (dilutions with sterile peptone were $\left.10^{-3}, 10^{-4}, 10^{-5}, 10^{-6}\right)$. Sample preparation was carried out in a laminar flow chamber. Compact Dry ${ }^{\circledR}$ TC plates were inoculated with $1 \mathrm{ml}$ of the dilutions and incubated at $35^{\circ} \mathrm{C}$ for $48 \mathrm{~h}$. Results were expressed as $\log _{10} \mathrm{cfu} / \mathrm{g}$. Two measurements were performed on each sample at each storage time.

\section{Statistical analysis}

The study followed a randomized complete block design (with 6 replications) in which each pork loin medallion steak was the experimental unit, being blocked by $L$. dorsi muscle. The effect of two factors: natural antioxidant (rosemary extract, ascorbic acid, rosemary extract + ascorbic acid and control) and storage time $(0,15,30$ and $45 \mathrm{~d})$ were evaluated by ANOVA (analysis of variance). The means of treatments were compared by Tukey's test $(\mathrm{p}<0.05)$. Data were analyzed with Statgraphics Centurion XV (StatPoint Tech, Inc., Warrenton, VA, USA). Results are reported as mean value \pm standard deviation (SD).

\section{RESULTS AND DISCUSSION}

The $\mathrm{pH}$ values were significantly affected by storage time; however, antioxidants (especially AA with low $\mathrm{pH}$ ) did not change them. Pork meat $\mathrm{pH}$ decreased at $45 \mathrm{~d}$ of refrigerated storage compared with the initial value at $0 \mathrm{~d}$, with significant differences in AA and RE+AA (Table 1). BLIXT \& BORCH (2002) reported similar behaviour in pork loin vacuumpackaged, where minimum $\mathrm{pH}$ value (5.2) was reached after 7 weeks of storage. The $\mathrm{pH}$ decrease during storage is partly attributed to the metabolite accumulation produced by lactic acid bacteria (DEMEYER et al., 1979), as they predominate in vacuum packaged meat (PIERSON et al., 1970). Lactobacillus development is encouraged by the oxygen-depleted condition in the evacuated package (BORCH et al., 1996). The $\mathrm{pH}$ of vacuum-packed meats is also affected by the carbon dioxide concentration present in the package, which is a metabolic by-product of microbial metabolism. Carbonic acid is formed when carbon dioxide produced by cellular respiration dissolves into the meat tissue, which acidifies the meat product (ADAMS et al., 2015). However, VIANA et al. (2005) did not observe modifications in the $\mathrm{pH}$ of pork $L$. dorsi muscle during $21 \mathrm{~d}$ of refrigerated storage under vacuum. APPLE et al. (2002) reported an increase of $\mathrm{pH}$ during vacuum storage of $L$. dorsi after 6 weeks.

Moisture and drip loss were significantly affected by storage time; the presence of antioxidants did not change drip loss and moisture. In terms of drip loss (Table 1) it was observed that samples initially (15d) have a high loss, with a smaller increase after $45 \mathrm{~d}$ (although significant, except for AA). This could be caused by changes in pressure during the packaging process, as described by CAYUELA et al. (2004). These authors reported drip loss of $5.1 \%$ (2d) to $8.8 \%$ (after 20d) in vacuum-storage of pork chops. KNOX et al. (2008)

Table $1-\mathrm{pH}$, moisture and drip loss values (means \pm SD) in pork $L$. dorsi steaks sprayed with natural antioxidants and packaged under vacuum during refrigerated storage $(0,15,30,45 \mathrm{~d})$ at $4^{\circ} \mathrm{C}$.

\begin{tabular}{|c|c|c|c|c|c|}
\hline & Time (d) & Control & Ascorbic acid & Rosemary extract & $\mathrm{RE}+\mathrm{AA}$ \\
\hline & 0 & $5.38 \pm 0.01 \mathrm{aA}^{*}$ & $5.37 \pm 0.03 \mathrm{aA}$ & $5.38 \pm 0.02 \mathrm{aA}$ & $5.39 \pm 0.03 \mathrm{aA}$ \\
\hline \multirow[t]{4}{*}{$\mathrm{pH}$} & 15 & $5.37 \pm 0.13 \mathrm{aA}$ & $5.34 \pm 0.13 \mathrm{abA}$ & $5.37 \pm 0.11 \mathrm{aA}$ & $5.37 \pm 0.14 \mathrm{aA}$ \\
\hline & 30 & $5.36 \pm 0.16 \mathrm{aA}$ & $5.36 \pm 0.18 \mathrm{abA}$ & $5.38 \pm 0.22 \mathrm{aA}$ & $5.36 \pm 0.17 \mathrm{abA}$ \\
\hline & 45 & $5.33 \pm 0.07 \mathrm{aA}$ & $5.30 \pm 0.06 \mathrm{bA}$ & $5.32 \pm 0.06 \mathrm{aA}$ & $5.29 \pm 0.09 \mathrm{bA}$ \\
\hline & 0 & $73.79 \pm 1.15 \mathrm{aA}$ & $73.54 \pm 1.15 \mathrm{aA}$ & $74.21 \pm 1.00 \mathrm{aA}$ & $73.23 \pm 1.08 \mathrm{aA}$ \\
\hline Moisture & 15 & $72.97 \pm 0.81 \mathrm{abA}$ & $73.15 \pm 1.01 \mathrm{abA}$ & $73.63 \pm 0.85 \mathrm{abA}$ & $72.97 \pm 0.33 \mathrm{aA}$ \\
\hline \multirow[t]{3}{*}{$(\%)$} & 30 & $73.42 \pm 0.82 \mathrm{abA}$ & $72.98 \pm 1.53 \mathrm{abA}$ & $73.15 \pm 0.66 \mathrm{bA}$ & $73.00 \pm 0.42 \mathrm{aA}$ \\
\hline & 45 & $72.89 \pm 1.03 \mathrm{bA}$ & $72.49 \pm 1.08 \mathrm{bA}$ & $72.83 \pm 0.47 \mathrm{bA}$ & $72.75 \pm 0.99 \mathrm{aA}$ \\
\hline & 15 & $5.0 \pm 1.6 \mathrm{aA}$ & $4.5 \pm 0.3 \mathrm{aA}$ & $5.3 \pm 1.6 \mathrm{aA}$ & $5.0 \pm 1.7 \mathrm{aA}$ \\
\hline Drip loss & 30 & $5.4 \pm 0.3 \mathrm{abA}$ & $5.3 \pm 1.6 \mathrm{aA}$ & $5.6 \pm 0.6 \mathrm{abA}$ & $5.1 \pm 1.0 \mathrm{abA}$ \\
\hline$(\%)$ & 45 & $6.3 \pm 1.8 \mathrm{bA}$ & $5.8 \pm 1.4 \mathrm{aA}$ & $6.8 \pm 1.4 \mathrm{bA}$ & $6.2 \pm 1.1 \mathrm{bA}$ \\
\hline
\end{tabular}

${ }^{*}$ Means within columns and parameter with different lower case letters are significantly different; means within rows with different capital letters are significantly different $(\mathrm{p}<0.05)$. $\mathrm{RE}+\mathrm{AA}$ : combination of rosemary extract and ascorbic acid. 
found drip loss of $3.6 \%$ to $7.9 \%$ with various ultimate $\mathrm{pH}$ groups over $34 \mathrm{~d}$ of storage at $4^{\circ} \mathrm{C}$ in vacuum-packaged pork loins. JEREMIAH et al. (1995) reported drip loss of $4.7 \%$ in pork loin under vacuum after 6 weeks of storage at $-1.5^{\circ} \mathrm{C}$. However APPLE et al. (2002) noticed that drip loss from loins remained relatively unchanged after 3 and 6 weeks of storage at $2^{\circ} \mathrm{C}(0.5 \%$ to $2.3 \%$ approximately $)$. As expected, moisture showed a similar behaviour to drip loss (Table 1). Pork meat samples diminished their water content after $45 \mathrm{~d}$ of refrigerated storage under vacuum. Similarly, there are reported moisture values of $72.2 \%$ in pork loins after 6 weeks of storage at $2^{\circ} \mathrm{C}$ under vacuum (APPLE et al., 2002).

Thiobarbituric acid reactive substances showed significant differences between antioxidants. TBARS values of pork meat sprayed with $\mathrm{RE}+\mathrm{AA}$ or $R E$ on the surface were significantly lower $(p<0.05)$ than the control (Table 2) after 45d of storage, AA did not differ from the control. Therefore, the most effective treatments to delay lipid oxidation were RE+AA and RE. Similar results were reported by SÁNCHEZESCALANTE et al. (2001) who reported that RE and RE+AA had a significant antioxidant effect during $20 \mathrm{~d}$ storage and the addition of AA was completely ineffective in preventing lipid oxidation of beef patties packaged in modified atmosphere. DJENANE et al. (2002) sprayed vitamin E, taurine and RE, in combination with AA on fresh beef steaks packaged in modified atmosphere. These authors reported a significant decrease in TBARS values (about 50\%) and concluded that RE in combination with AA was the most effective treatment in delaying myoglobin and lipid oxidation. DJENANE et al. (2003) investigated the effect of RE in combination with AA under UVfree lighting in beef steaks packaged in modified atmosphere. They concluded that the absence of UV radiation and the treatment with an antioxidant mixture of RE and AA significantly extended meat display life from about 10 days to about 20 days.
TBARS values did not change with storage time. CAYUELA et al. (2004) reported no differences in TBARS in pork $L$. dorsi muscle packaged under vacuum (without antioxidants) during $20 \mathrm{~d}$ of refrigerated storage. Similar results were obtained by GODZISZEWSKA et al. (2017) in pork loin packaged under vacuum after 12 days of refrigerated storage.

Mean color measurements on pork steaks with or without spraying antioxidants during storage are shown in table 3 . No significant effect of storage time or natural antioxidants on $\mathrm{L}^{*}$ values were observed. Natural antioxidants did not affect $\mathrm{a}^{*}$ and $b^{*}$ coordinates. However, $a^{*}$ and $b^{*}$ were significantly affected by storage time, as both color coordinates increased during storage. These results are consistent with other authors findings, HOLMER et al. (2009) reported a slight increase in $\mathrm{a}^{*}$ and $\mathrm{b}^{*}$ values from 0 to $28 \mathrm{~d}$ of storage, indicating that vacuum packaged pork becomes redder and more yellow over time. LINDAHL (2005) observed that storage under vacuum for 8-9 days increased lightness, redness and yellowness in pork muscles compared with samples preserved for 1-2 days. ROSENVOLD \& ANDERSEN (2003) reported higher $\mathrm{a}^{*}$ and $\mathrm{b}^{*}$ values after $8 \mathrm{~d}$ of vacuum storage of pork meat however, no differences in $\mathrm{L}^{*}$ were found. FREDERICK et al. (2004) reported higher redness and yellowness but lower lightness in L. dorsi pork after 25 or 50 days under vacuum storage compared with 24 hour postmortem muscle samples. BERIAIN et al. (2009) reported that $\mathrm{a}^{*}$ and $\mathrm{b}^{*}$ increased during 14 days of ageing in beef under vacuum, $\mathrm{L}^{*}$ showed no significant effect remaining constant during this period.

Total aerobic counts (TAC) on pork steaks, with or without antioxidants during storage, are shown in figure 1. TAC was significantly affected by storage time; however, antioxidants did not affect them. Spraying with RE, AA and $\mathrm{RE}+\mathrm{AA}$ on the surface of meat was not sufficient to delay the growth

Table 2 - TBARS (mg MDA $/ \mathrm{kg}$ meat) in pork L. dorsi steaks (means \pm SD) sprayed with natural antioxidants and packaged under vacuum during refrigerated storage $(0,15,30,45 \mathrm{~d})$ at $4^{\circ} \mathrm{C}$.

\begin{tabular}{cccccc}
\hline & Time (d) & Control & Ascorbic acid & Rosemary extract \\
\hline TBARS & 0 & $0.71 \pm 0.10 \mathrm{aA}^{*}$ & $0.69 \pm 0.14 \mathrm{aA}$ & $0.64 \pm 0.15 \mathrm{aA}$ & $0.61 \pm 0.21 \mathrm{aA}$ \\
& 15 & $0.73 \pm 0.12 \mathrm{aA}$ & $0.68 \pm 0.12 \mathrm{aA}$ & $0.63 \pm 0.07 \mathrm{aA}$ & $0.61 \pm 0.17 \mathrm{aA}$ \\
& 30 & $0.71 \pm 0.06 \mathrm{aA}$ & $0.71 \pm 0.15 \mathrm{aA}$ & $0.63 \pm 0.07 \mathrm{aA}$ & $0.62 \pm 0.15 \mathrm{aA}$ \\
& 45 & $0.79 \pm 0.10 \mathrm{aA}$ & $0.72 \pm 0.12 \mathrm{aAB}$ & $0.66 \pm 0.17 \mathrm{aB}$ & $0.65 \pm 0.18 \mathrm{aB}$
\end{tabular}

\footnotetext{
*Means within columns with different lower case letters are significantly different; means within rows with different capital letters are significantly different $(\mathrm{p}<0.05)$. RE+AA: combination of rosemary extract and ascorbic acid.
} 
Table $3-\mathrm{L}^{*}$, $\mathrm{a}^{*}$ and $\mathrm{b}^{*}$ values (means $\pm \mathrm{SD}$ ) in pork $L$. dorsi steaks sprayed with natural antioxidants and packaged under vacuum during refrigerated storage $(0,15,30,45 \mathrm{~d})$ at $4^{\circ} \mathrm{C}$.

\begin{tabular}{|c|c|c|c|c|c|}
\hline & Time (d) & Control & Ascorbic acid & Rosemary extract & $\mathrm{RE}+\mathrm{AA}$ \\
\hline & 0 & $56.60 \pm 7.74 \mathrm{aA}^{*}$ & $55.38 \pm 6.60 \mathrm{aA}$ & $55.93 \pm 7.71 \mathrm{aA}$ & $56.14 \pm 6.14 \mathrm{aA}$ \\
\hline \multirow[t]{4}{*}{$\mathrm{L}^{*}$} & 15 & $56.17 \pm 3.97 \mathrm{aA}$ & $57.52 \pm 3.76 \mathrm{aA}$ & $55.10 \pm 4.56 \mathrm{aA}$ & $55.22 \pm 4.20 \mathrm{aA}$ \\
\hline & 30 & $53.03 \pm 1.93 \mathrm{aA}$ & $53.42 \pm 2.53 \mathrm{aA}$ & $51.84 \pm 2.43 \mathrm{aA}$ & $54.43 \pm 4.18 \mathrm{aA}$ \\
\hline & 45 & $56.25 \pm 4.28 \mathrm{aA}$ & $56.69 \pm 3.58 \mathrm{aA}$ & $55.23 \pm 4.77 \mathrm{aA}$ & $57.29 \pm 4.69 \mathrm{aA}$ \\
\hline & 0 & $9.23 \pm 1.49 \mathrm{aA}$ & $9.62 \pm 1.67 \mathrm{aA}$ & $9.68 \pm 1.62 \mathrm{aA}$ & $9.75 \pm 1.29 \mathrm{aA}$ \\
\hline \multirow[t]{4}{*}{$a^{*}$} & 15 & $9.56 \pm 1.53 \mathrm{abA}$ & $9.57 \pm 1.80 \mathrm{aA}$ & $9.87 \pm 1.18 \mathrm{abA}$ & $10.62 \pm 1.81 \mathrm{abA}$ \\
\hline & 30 & $10.07 \pm 1.13 \mathrm{bcA}$ & $9.59 \pm 0.56 \mathrm{abA}$ & $10.50 \pm 0.84 \mathrm{bcA}$ & $10.59 \pm 0.88 \mathrm{bcA}$ \\
\hline & 45 & $11.06 \pm 1.95 \mathrm{cA}$ & $11.20 \pm 1.69 \mathrm{bA}$ & $11.39 \pm 2.11 \mathrm{cA}$ & $11.52 \pm 1.24 \mathrm{cA}$ \\
\hline & 0 & $9.37 \pm 2.22 \mathrm{aA}$ & $9.64 \pm 2.50 \mathrm{aA}$ & $10.49 \pm 2.56 \mathrm{aA}$ & $10.50 \pm 2.22 \mathrm{aA}$ \\
\hline \multirow[t]{3}{*}{$b^{*}$} & 15 & $10.87 \pm 2.59 \mathrm{abA}$ & $10.78 \pm 2.32 \mathrm{abA}$ & $11.49 \pm 2.54 \mathrm{abA}$ & $11.37 \pm 1.77 \mathrm{abA}$ \\
\hline & 30 & $11.40 \pm 1.36 \mathrm{bA}$ & $11.46 \pm 1.30 \mathrm{bcA}$ & $12.03 \pm 1.71 \mathrm{bA}$ & $12.25 \pm 1.69 \mathrm{bA}$ \\
\hline & 45 & $11.98 \pm 1.98 \mathrm{bA}$ & $12.75 \pm 2.00 \mathrm{cA}$ & $12.65 \pm 2.64 \mathrm{bA}$ & $12.87 \pm 1.14 \mathrm{bA}$ \\
\hline
\end{tabular}

*Means within columns and parameter with different lower case letters are significantly different; means within rows with different capital letters are significantly different $(\mathrm{p}<0.05)$. RE+AA: combination of rosemary extract and ascorbic acid.

of total aerobic bacteria in pork vacuum packaged steaks up to 45 days in refrigerated storage. As for TAC, it was observed that it significantly increased during storage. The initial population was $4.2-4.4 \log$ $\mathrm{cfu} / \mathrm{g}$. Microbial counts increased steadily throughout storage, reaching $6.2-7.2 \log \mathrm{cfu} / \mathrm{g}$ after $45 \mathrm{~d}$. TAC values in excess of $10^{7} \mathrm{cfu} / \mathrm{g}$ detected on fresh meat suggests an incipient spoilage (ICMSF, 1986).

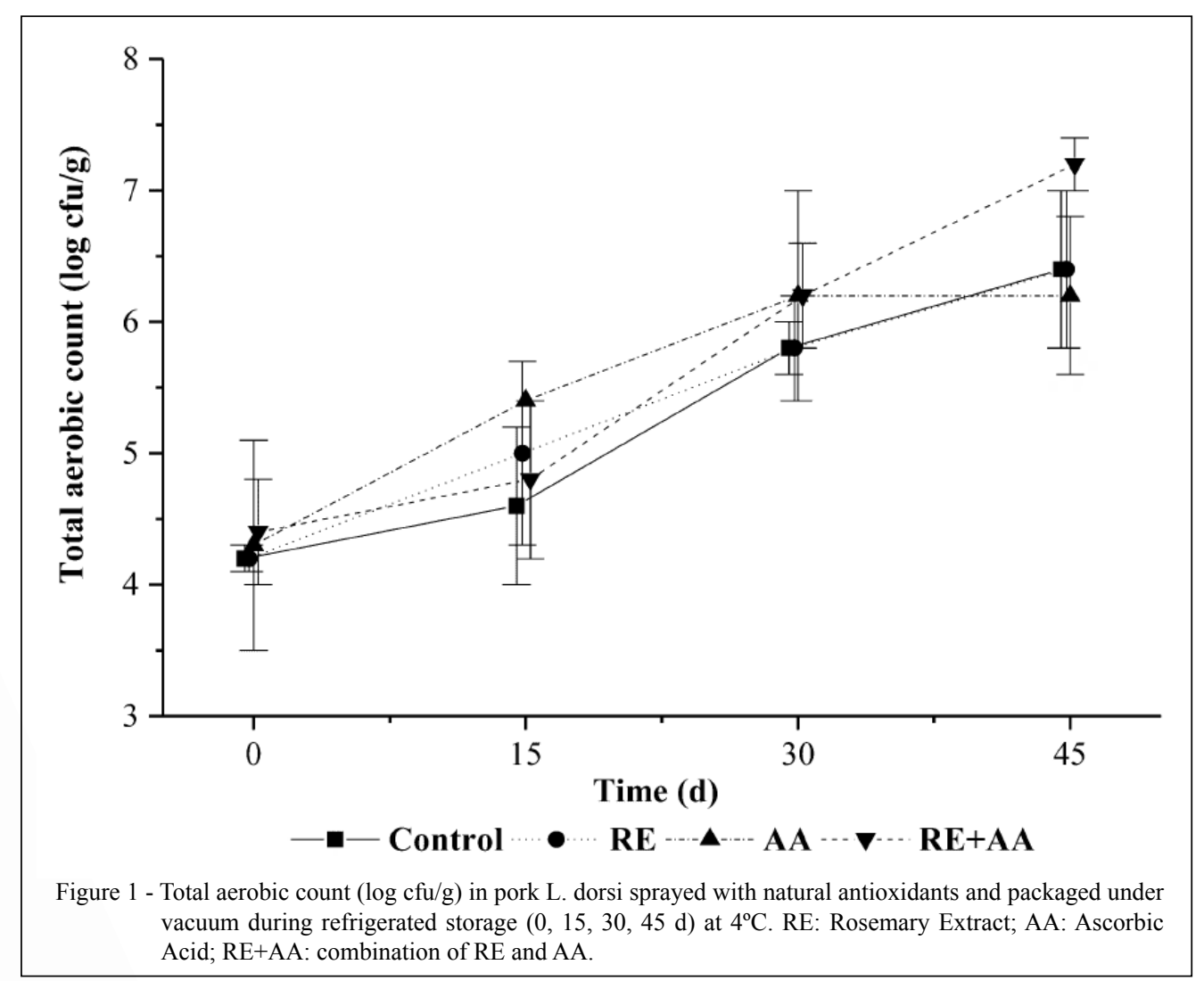

Ciência Rural, v.48, n.4, 2018. 
There is general agreement that the bacterial flora is dominated by lactic acid bacteria in vacuum packaging (PIERSON et al., 1970; BORCH et al., 1996). ZHAO et al. (2015) studied microbial composition in vacuum packaged chilled pork during 21 days of storage. These authors reported that abundance of Flavobacteriaceae on pork surface remained high during the first 7 days, but its abundance continuously decreased with longer storage times. Indeed Lactobacillaceae and Carnobacteriaceae were the major components of the microflora in vacuum packed chilled pork at day 14 and 21d of storage.

Taking into account natural antioxidant effectiveness, FERNÁNDEZ-LÓPEZ et al. (2005) have reported a non significant reduction of lactic acid bacteria counts in beef meatballs containing RE after 12 days of refrigerated storage and packaged with semi-permeable film. SÁNCHEZ-ESCALANTE et al. (2001) did not found antimicrobial effect of RE, AA or their combination in beef patties packaged in modified atmosphere and refrigerated during 20 days. OKAYAMA et al. (1987) treated beef loin steaks with AA and ethanol, and reported that there was no difference in the viable bacterial count with a treated with ethanol only control, after $13 \mathrm{~d}$ of storage at $4^{\circ} \mathrm{C}$ in hermetically sealed plastic containers. However, several authors have reported certain compounds present in the rosemary extract as responsible for antimicrobial activity. Non polar components such as phenolic diterpenes (responsible for the antimicrobial properties of rosemary) are generally considered effective only against Gram-positive bacteria (FERNÁNDEZ-LÓPEZ et al., 2005) like lactic acid. This behavior was not observed in the present study with RE or the combination of RE+AA.

\section{CONCLUSION}

Pork meat surface sprayed with rosemary extract or a combination of rosemary extract and ascorbic acid exhibited lipid antioxidant activity during refrigerated stored. No effect of antioxidant addition on $\mathrm{pH}$, color, drip loss, moisture or total aerobic count of vacuum-packed pork meat was observed during storage. These data suggested that spraying rosemary extract alone (4000ppm total phenols) or in combination with ascorbic acid (500ppm) on the surface of vacuum-packed fresh pork could be used as an antioxidant method.

\section{ACKNOWLEDGEMENTS}

The authors wish to acknowledge Ms Alicia Noceti's assistance with the English language editing. This research was funded by SCyT, Universidad Nacional de Entre Rios (UNER), Argentina.

\section{DECLARATION OF CONFLICTING INTERESTS}

The authors declared no potential conflicts of interest with respect to the research, authorship, and/or publication of this article.

\section{REFERENCES}

ADAMS, K.R. etal. Dissolved carbon dioxide and oxygen concentrations in purge of vacuum-packaged pork chops and the relationship to shelf life and models for estimating microbial populations. Meat Science, v.110, p.1-8, 2015. doi: 10.1016/j.meatsci.2015.06.003.

AOAC. ASSOCIATION OF OFFICIAL ANALYTICAL CHEMISTS. Official Methods of Analysis, 18th Ed., Association of Official Analytical Chemists, Maryland, 2005.

APPLE, J.K. et al. Halothane-genotype and duration of refrigerated storage effects on the quality of vacuum-packaged pork loins. Journal of Muscle Foods, v.13, p.103-122, 2002. Available from: <http:// onlinelibrary.wiley.com/doi/10.1111/j.1745-4573.2002.tb00324.x/full>. Accessed: Mar.31,2017. doi: 10.1111/j.1745-4573.2002.tb00324.x.

BERIAIN, M. et al. Predicting Longissimus dorsi myoglobin oxidation in aged beef based on early post-mortem colour measurements on the carcass as a colour stability index. Meat Science, v.81, p.439-445, 2009. doi: 10.1016/j.meatsci.2008.09.009.

BLIXT, Y., BORCH, E. Comparison of shelf life of vacuumpacked pork and beef. Meat Science, v.60, p.371-378, 2002. doi: 10.1016/S0309-1740(01)00145-0.

$\mathrm{BORCH}$, E. et al. Bacterial spoilage of meat products and cured meat. International Journal of Food Microbiology, v.33, p.103-120, 1996. Available from: $<$ http://www.sciencedirect.com/science/article/ pii/016816059601135X>. Accessed: Mar. 31, 2017. doi: 10.1016/01681605(96)01135-X.

CAYUELA, J.M. et al. Effect of vacuum and modified atmosphere packaging on the quality of pork loin. European Food Research and Technology, v.219, p.316-320, 2004. doi: 10.1007/s00217-004-0970-x.

CIE. International commission on illumination, recommendations on uniform colour spaces, colour difference equations, psychometric colour terms. Supplement No. 15 to CIE publication (E-1.3.1) 1971/ (TO-1.3). Bureau Central de la CIE, Paris, France, 1978.

DECKER, E.A., XU, Z. Minimizing rancidity in muscle foods. Food Technology, v.52, p.54-59, 1998.

DEL CAMPO, J. et al. Antimicrobial effect of rosemary extracts. Journal of Food Protection, v.63, n.10, p.1359-1368, 2000.

DEMEYER, D. et al. Compounds determining $\mathrm{pH}$ in dry sausage. Meat Science, v.3, n.3, p.161-167, 1979. doi: 10.1016/03091740(79)90033-0.

DJENANE, D. et al. Ability of alpha-tocopherol, taurine and rosemary, in combination with vitamin $\mathrm{C}$, to increase the oxidative stability of beef steaks packaged in modified atmosphere. Food Chemistry, v.76, p.407-415, 2002. Available from: <http://www. sciencedirect.com/science/article/pii/S0308814601002862>. Accessed: Mar. 31, 2017. doi: 10.1016/S0308-8146(01)00286-2.

DJENANE, D. et al. Extension of the shelf life of beef steaks packaged in a modified atmosphere by treatment with rosemary 
and displayed under UV-free lighting. Meat Science, v.64, p.417426, 2003. doi: 10.1016/S0309-1740(02)00210-3.

ELLIOTT, J.G. Application of antioxidant vitamins in foods and beverages. Food Technology, v.53, p.46-48, 1999.

FERNÁNDEZ-LÓPEZ, J. et al. Antioxidant and antibacterial activities of natural extracts: application in beef meatball. Meat Science, v.69, p.371-380, 2005. doi: 10.1016/j.meatsci.2004.08.004

FREDERICK, B.R. et al. Timing of magnesium supplementation administered through drinking water to improve fresh and stored pork quality. Journal of Animal Science, v.82, p.1454-1460, 2004. Available from: <https:/www.animalsciencepublications. org/publications/jas/pdfs/82/5/0821454>. Accessed: Mar. 31, 2017. doi: $10.2527 / 2004.8251454 \mathrm{x}$.

GEORGANTELIS, D. et al. Effect of rosemary extract, chitosan and a-tocopherol on microbiological parameters and lipid oxidation of fresh pork sausages stored at $4^{\circ} \mathrm{C}$. Meat Science, v.76, p.172181, 2007. doi: 10.1016/j.meatsci.2006.10.026

GODZISZEWSKA, J. et al. Nutrient oxidation in pork loin is influenced by feed supplementation and packing methods. Journal of Food Composition and Analysis, v.56, p.18-24, 2017. Available from: $<$ http:// www.sciencedirect.com/science/article/pii/S0889157516302083>. Accessed: Mar. 31, 2017. doi: 10.1016/j.jfca.2016.11.009.

HOLMER, S.F. et al. The effect of $\mathrm{pH}$ on shelf-life of pork during aging and simulated retail display. Meat Science, v.82, p.86-93, 2009. doi: 10.1016/j.meatsci.2008.12.008.

ICMSF. Microorganisms in Foods 2. Sampling for microbiological analysis: Principles and specific applications. 2nd Ed. International Commission on Microbiological Specifications for Foods. Blackwell Scientific Publications, Oxford UK. 1986.

JEREMIAH, L.E. et al. The influence of controlled atmosphere and vacuum packaging upon chilled pork keeping quality. Meat Science, v.40, n.1, p.79-92, 1995. doi: 10.1016/0309-1740(94)00025-3.

KNOX, B.L. et al. Relationships between ultimate $\mathrm{pH}$ and microbial, chemical, and physical characteristics of vacuum-packaged pork loins. Journal of Food Science, v.73, n.3, p.104-110, 2008 Available from: $\quad<$ http://onlinelibrary.wiley.com/doi/10.1111/ j.1750-3841.2008.00667.x/pdf $>$. Accessed: Mar. 31, 2017. doi: 10.1111/j.1750-3841.2008.00667.x.

LINDAHL, G. Colour Characteristics of Fresh Pork. Doctoral thesis. Swedish University of Agricultural Sciences. 2005. Available from: $<$ http://pub.epsilon.slu.se/827/1/Thesis.pdf $>$. Accessed: Mar. 31, 2017.

MITSUMOTO, M. et al. Vitamins E and C Improve Pigment and Lipid Stability in Ground Beef. Journal of Food Science, v.56, p.194-197, 1991. Available from: <http://onlinelibrary.wiley.com/ doi/10.1111/j.1365-2621.1991.tb08010.x/pdf>. Accessed: Mar. 31, 2017. doi: 10.1111/j.1365-2621.1991.tb08010.x.

NAVEENA, B.M. et al. Comparative efficacy of pomegranate juice, pomegranate rind powder extract and BHT as antioxidants in cooked chicken patties. Meat Science, v.80, p.1304-1308, 2008. doi: 10.1016/j.meatsci.2008.06.005.

NISSEN, L.R. et al. The antioxidative activity of plant extracts in cooked pork patties as evaluated by descriptive sensory profiling and chemical analysis. Meat Science, v.68, p.485-495, 2004. doi: 10.1016/j.meatsci.2004.05.004.

OKAYAMA, T. et al. Effect of ascorbic acid and alpha-tocopherol on storage stability of beef steaks. Meat Science, v.21, n.4, $267-$ 273, 1987. doi: 10.1016/0309-1740(87)90063-5.

PIERSON, M.D. et al. Microbiological, sensory and pigment changes of aerobically and anaerobically packaged beef. Food Technology, v.24, p.129-133, 1970.

PIKUL, J. et al. Evaluation of three modified TBA methods for measuring lipid oxidation in chicken meat. Journal of Agriculture and Food Chemistry, v.37, p.1309-1313, 1989. doi: 10.1021/jf00089a022.

ROJAS, M.C., BREWER, M.S. Effect of natural antioxidants on oxidative stability of frozen, vacuum-packaged beef and pork. Journal of Food Quality, v.31, p.173-188, 2008. Available from: <http:/ onlinelibrary.wiley.com/doi/10.1111/j.1745-4557.2008.00196.x/full>. Accessed: Mar. 31, 2017. doi: 10.1111/j.1745-4557.2008.00196.x.

ROSENVOLD, K., ANDERSEN, H.J. The significance of pre-slaughter stress and diet on colour and colour stability. Meat Science, v.63, p.199-209, 2003. doi: 10.1016/S03091740(02)00071-2.

SÁNCHEZ-ESCALANTE, A. et al. The effects of ascorbic acid, taurine, carnosine and rosemary powder on colour and lipid stability of beef patties packaged in modified atmosphere. Meat Science, v.58, p.421-429, 2001. doi: 10.1016/S0309-1740(01)00045-6.

SÁNCHEZ-ESCALANTE, A. et al. Antioxidant action of borage, rosemary, oregano, and ascorbic acid in beef patties packaged in modified atmosphere. Journal of Food Science, v.68, p.339-344, 2003. Available from: <http://onlinelibrary.wiley.com/doi/10.1111/j.1365-2621.2003. tb14162.x/full $>$. Accessed: Mar. 31, 2017. doi: 10.1111/j.13652621.2003.tb14162.x.

VIANA, E.S. et al. Effect of modified atmospheres on microbiological, colour and sensory properties of refrigerated pork. Meat Science, v.71, p.696-705, 2005. doi: 10.1016/j. meatsci.2005.05.013.

ZHAO, F. et al. Microbial changes in vacuum-packed chilled pork during storage. Meat Science, v.100, p.145-149, 2015. doi: 10.1016/j.meatsci.2014.10.004. 